\title{
Reply to Chou et al 'Do significant TFE3 gene rearrangements occur in succinate dehydrogenase deficient renal cell carcinoma? Borderline FISH results should be interpreted with caution' Mod Pathol 2017; in press.
}

\author{
Modern Pathology (2017) 30, 1509-1511; doi:10.1038/modpathol.2017.84
}

To the Editor: We greatly appreciate the interest of Chou et $a l^{1}$ in our recent work reporting the coexistence of TFE3 gene rearrangement and alterations of $S D H B$ in renal cell carcinoma. ${ }^{2}$ Indeed, as the authors note, it seems counterintuitive to find these two alterations in the same neoplasm, which might be hypothesized to be mutually exclusive, since both are presumed to be key driver events in tumorigenesis. However, with increasing application of molecular techniques, ${ }^{3,4}$ it is now also apparent that some neoplasms exhibit overlapping and complex alterations. ${ }^{5}$ Coexistence of translocation with key driver mutations in the same tumor has been reported previously. ${ }^{6-8}$ The same alterations may produce different phenotypes in different tumor types or body sites, and there may be considerable clonal evolution and clonal heterogeneity within a single tumor or metastases. , $^{9,10}$

It is not unprecedented to hypothesize that some alterations may occur as secondary events in tumors driven by other genetic alterations, including renal cell carcinoma. As examples relevant to the study discussed here, Papathomas et $\mathrm{ll}^{11}$ encountered one renal cell carcinoma from a cohort of 348 unselected tumors (including 130 renal tumors) that exhibited abnormal negative SDHB immunohistochemical staining in the high-grade component of a clear cell renal cell carcinoma. Genetic studies demonstrated large intragenic $S D H D$ and $S D H A F 2$ deletions in only this high-grade and sarcomatoid component of this tumor, with absence of germline mutation, suggesting that in this case SDH subunit alterations occurred as a secondary event in a tumor likely representing a usual clear cell renal cell carcinoma. ${ }^{11}$ Conversely, another recent study suggested that some gene fusions with TFEB may be secondary, occurring in the setting of amplification, rather than as a main driver event, ${ }^{12}$ a phenomenon that has also been reported in other contexts. ${ }^{13}$ As another example, some of us have found that from the Cancer Genome Atlas database of clear cell renal cell carcinoma, ${ }^{14}$ two tumors were recently noted to be TFE3-SFPQ rearrangement-associated tumors ${ }^{8}$ also had VHL gene mutation, chromosome 3p deletion, and morphology indistinguishable from clear cell renal cell carcinoma, ${ }^{15}$ suggesting that there may be unexpected overlap in molecular alterations between tumor histologies, especially as various testing techniques with varying sensitivities are employed.

As noted by Chou et $a l^{1}$ the fraction of cells showing a TFE3 gene rearrangement pattern in our study was low ${ }^{2}$ which is also somewhat counterintuitive, as one might predict an overwhelming majority of tumor cells to harbor a molecular alteration if it were the main driver event of tumorigenesis. However, a number of studies on TFE3 rearrangement-associated renal cell carcinoma have used similar cutoff thresholds, ${ }^{16,17}$ with possible explanations for the low fraction of rearrangement signals including nuclear truncation due to histologic sectioning, inability to distinguish normal from neoplastic cells during evaluation, and tendency to underestimate the composition of normal cells in tumor tissues. ${ }^{3,4,16,18,19}$ Strong immunohistochemical labeling for TFE3 has been found to be a reliable biomarker of TFE3 translocation. In our study, all of the cases were also strongly positive by TFE3 immunohistochemical staining, which may support abnormal protein production, although of course fluorescence in situ hybridization (FISH) is generally considered superior for detecting true translocation in this context. ${ }^{2,16,20,21}$

The particular cases reported in our study were identified because of the unusual morphologic features that, despite areas morphologically suggestive of SDH-deficient renal cell carcinoma, also raised the possibility of translocation-associated carcinoma and prompted immunohistochemical evaluation for TFE3 protein. This included a papillary architecture in three tumors with psammomatous calcifications in two. These features have been rarely described in series of SDH-deficient renal cell carcinoma in the literature. ${ }^{22,23}$ One case included in the series from Gill et $a l^{22}$ had a predominant papillary architecture, whereas only 'very focal abortive papillary architecture' was noted in a few cases. The study by Williamson et $a l^{23}$ did not identify any neoplasms with papillary architecture, although most of the tumors in both studies were identified based on morphologic suspicion rather than unselected screening, which might introduce a bias toward detection of those with prototypical morphology. Although limited pathology data are provided, the study by Ricketts et $a l^{24}$ also noted 
some tumors in patients with known SDH subunit gene mutations to be usual clear cell renal cell carcinomas, suggesting that the morphology of SDH-deficient renal cell carcinomas may be more heterogeneous when patients are identified based on known gene mutations rather than tumor morphology.

In the study by Green et $a{ }^{16}{ }^{16}$ seven of the 31 tumors interpreted as TFE3 rearranged had a split signal FISH pattern making up less than $40 \%$ of cells $(16-37 \%)$. This raises an intriguing question for future research, as to whether all of these tumors should be considered biologically equivalent, or whether there are differences between tumors with high and low percentages of rearranged cells. This question becomes increasingly relevant, as the spectrum of TFE3 rearranged renal cell carcinoma continues to expand to include a highly heterogeneous group of renal cell carcinomas with morphology beyond that which was initially described. ${ }^{16,20,25}$ Cutoff values for TFE3 translocation have also varied among studies from $7 \%$ in one study ${ }^{26}$ to $20 \%$ in another study. ${ }^{27}$ Chou et al indicate that in their laboratory a cutoff of $\geq 10 \%$ is utilized.

Overall, we agree with the interpretation of Chou et al that in the reported tumors, SDHB alterations are likely to represent the primary driver alteration; nonetheless, our finding may have relevance in the diagnostic setting and for understanding of intratumoral heterogeneity and clonal evolution. As such, when encountering a mutation, rearrangement, or other molecular alteration in an unusual or unexpected context, it may be warranted for pathologists and scientists to keep open consideration for other alterations, such as the scenario of diagnosing renal cell carcinoma in young patients posed by Chou et al. The clinical and biological significance of TFE3 translocation also remain to be further explored; an increasing number of non-renal tumors also harbor TFE3 translocation, including perivascular epithelioid cell neoplasms (PEComas) and rare ovarian tumors, in addition to the prototypical entity, alveolar soft part sarcoma. ${ }^{27-34}$

\section{Disclosure/conflict of interest}

The authors declare no conflict of interests.

Sean R Williamson ${ }^{1}$, David J Grignon ${ }^{2}$,
Anna Calióo ${ }^{2,3}$, Bradley A Stohr ${ }^{4}, \begin{array}{r}\text { John N Eble }{ }^{2} \text { and } \\ \text { Liang Cheng }\end{array}$
${ }^{2}$ Department of Pathology and Laboratory Medicine,
Henry Ford Health System, Detroit, Michigan, USA;
${ }^{2}$ Department of Pathology and Laboratory Medicine,
Indiana University School of Medicine, Indianapolis,
Indiana, USA; ${ }^{3}$ Department of Pathology, University
of Verona, Verona, Italy; ${ }^{4}$ Department of Pathology,
University of California San Francisco, San
Francisco, California, USA
E-mail: liang_cheng@yahoo.com

\section{References}

1 Chou A, Hes O, Turchini J, et al. Do significant TFE3 gene rearrangements occur in succinate dehydrogenase deficient renal cell carcinoma? Borderline FISH results should be interpreted with caution. Mod Pathol 2017, (this issue).

2 Calio A, Grignon DJ, Stohr BA, et al. Renal cell carcinoma with TFE3 translocation and succinate dehydrogenase B mutation. Mod Pathol 2017;30: 407-415.

3 Cheng L, Eble JN. Molecular Surgical Pathology. Springer: New York, NY, 2013.

4 Cheng L, Zhang S, Wang L, et al. Fluorescence in situ hybridization in surgical pathology: principles and applications. J Pathol Clin Res 2017;3:73-99.

5 Vogelstein B, Papadopoulos N, Velculescu VE, et al. Cancer genome landscapes. Science 2013;339: 1546-1558.

6 Cai W, Lin D, Wu C, et al. Intratumoral heterogeneity of ALK-rearranged and ALK/EGFR coaltered lung adenocarcinoma. J Clin Oncol 2015;33:3701-3709.

7 Parast MM, Eudy G, Gow KW, et al. A unique case of renal carcinoma with Xp11.2 translocations/TFE3 gene fusions in a 3-year-old child, with coexistent von Hippel-Lindau gene mutation. Pediatr Dev Pathol 2004;7:403-406.

8 Malouf GG, Su X, Yao $\mathrm{H}$, et al. Next-generation sequencing of translocation renal cell carcinoma reveals novel RNA splicing partners and frequent mutations of chromatin-remodeling genes. Clin Cancer Res 2014;20:4129-4140.

9 McGranahan N, Swanton C. Clonal heterogeneity and tumor evolution: past, present, and the future. Cell 2017;168:613-628.

10 McGranahan N, Favero F, de Bruin EC, et al. Clonal status of actionable driver events and the timing of mutational processes in cancer evolution. Sci Transl Med 2015;7:283ra254.

11 Papathomas TG, Gaal J, Corssmit EP, et al. Nonpheochromocytoma (PCC)/paraganglioma (PGL) tumors in patients with succinate dehydrogenase-related PCC-PGL syndromes: a clinicopathological and molecular analysis. Eur J Endocrinol 2014;170:1-12.

12 Williamson SR, Grignon DJ, Cheng L, et al. Renal cell carcinoma with chromosome $6 \mathrm{p}$ amplification including the TFEB gene: a novel mechanism of tumor pathogenesis? Am J Surg Pathol 2017;41:287-298.

13 Kalyana-Sundaram S, Shankar S, Deroo S, et al. Gene fusions associated with recurrent amplicons represent a class of passenger aberrations in breast cancer. Neoplasia 2012;14:702-708.

14 Cancer Genome Atlas Research Network. Comprehensive molecular characterization of clear cell renal cell carcinoma. Nature 2013;499:43-49.

15 Favazza L, Chitale DA, Barod R, et al. Renal cell tumors with clear cell histology and intact VHL and chromosome 3p: a histological review of tumors from the Cancer Genome Atlas database. Mod Pathol 2017; in press.

16 Green WM, Yonescu R, Morsberger L, et al. Utilization of a TFE3 break-apart FISH assay in a renal tumor consultation service. Am J Surg Pathol 2013;37: 1150-1163.

17 Hayes M, Peckova K, Martinek P, et al. Moleculargenetic analysis is essential for accurate classification of renal carcinoma resembling Xp11.2 translocation carcinoma. Virchows Arch 2015;466:313-322. 
18 Saxe DF, Persons DL, Wolff DJ, et al. Validation of fluorescence in situ hybridization using an analytespecific reagent for detection of abnormalities involving the mixed lineage leukemia gene. Arch Pathol Lab Med 2012;136:47-52.

19 Cheng L, Zhang D, Eble JN. Molecular Genetic Pathology, 2nd ed. Springer: New York, NY, 2013.

20 Rao Q, Williamson SR, Zhang S, et al. TFE3 break-apart FISH has a higher sensitivity for Xp11.2 translocationassociated renal cell carcinoma compared with TFE3 or cathepsin $\mathrm{K}$ immunohistochemical staining alone: expanding the morphologic spectrum. Am J Surg Pathol 2013;37:804-815.

21 Argani P, Lal P, Hutchinson B, et al. Aberrant nuclear immunoreactivity for TFE3 in neoplasms with TFE3 gene fusions: a sensitive and specific immunohistochemical assay. Am J Surg Pathol 2003;27:750-761.

22 Gill AJ, Hes O, Papathomas T, et al. Succinate dehydrogenase (SDH)-deficient renal carcinoma: a morphologically distinct entity: a clinicopathologic series of 36 tumors from 27 patients. Am J Surg Pathol 2014;38:1588-1602.

23 Williamson SR, Eble JN, Amin MB, et al. Succinate dehydrogenase-deficient renal cell carcinoma: detailed characterization of 11 tumors defining a unique subtype of renal cell carcinoma. Mod Pathol 2015;28: 80-94.

24 Ricketts CJ, Shuch B, Vocke CD, et al. Succinate dehydrogenase kidney cancer: an aggressive example of the Warburg effect in cancer. J Urol 2012;188: 2063-2071.

25 Argani P, Yonescu R, Morsberger L, et al. Molecular confirmation of $\mathrm{t}(6 ; 11)(\mathrm{p} 21 ; \mathrm{q} 12)$ renal cell carcinoma in archival paraffin-embedded material using a breakapart TFEB FISH assay expands its clinicopathologic spectrum. Am J Surg Pathol 2012;36:1516-1526.

26 Pradhan D, Roy S, Quiroga-Garza G, et al. Validation and utilization of a TFE3 break-apart FISH assay for
Xp11.2 translocation renal cell carcinoma and alveolar soft part sarcoma. Diagn Pathol 2015;10:179.

27 Hodge JC, Pearce KE, Wang X, et al. Molecular cytogenetic analysis for TFE3 rearrangement in Xp11.2 renal cell carcinoma and alveolar soft part sarcoma: validation and clinical experience with 75 cases. Mod Pathol 2014;27:113-127.

28 Argani P, Antonescu CR, Illei PB, et al. Primary renal neoplasms with the ASPL-TFE3 gene fusion of alveolar soft part sarcoma: a distinctive tumor entity previously included among renal cell carcinomas of children and adolescents. Am J Pathol 2001;159:179-192.

29 Ladanyi M, Lui MY, Antonescu CR, et al. The der(17)t $(\mathrm{X} ; 17)(\mathrm{p} 11 ; \mathrm{q} 25)$ of human alveolar soft part sarcoma fuses the TFE3 transcription factor gene to ASPL, a novel gene at 17q25. Oncogene 2001;20:48-57.

30 Rekhi B, Ingle A, Agarwal M, et al. Alveolar soft part sarcoma 'revisited': clinicopathological review of 47 cases from a tertiary cancer referral centre, including immunohistochemical expression of TFE3 in 22 cases and 21 other tumours. Pathology 2012;44:11-17.

31 Williamson SR, Bunde PJ, Montironi R, et al. Malignant perivascular epithelioid cell neoplasm (PEComa) of the urinary bladder with TFE3 gene rearrangement: clinicopathologic, immunohistochemical, and molecular features. Am J Surg Pathol 2013;37:1619-1626.

32 Shen Q, Rao Q, Xia QY, et al. Perivascular epithelioid cell tumor (PEComa) with TFE3 gene rearrangement: clinicopathological, immunohistochemical, and molecular features. Virchows Arch 2014;465:607-613.

33 Schoolmeester JK, Dao LN, Sukov WR, et al. TFE3 translocation-associated perivascular epithelioid cell neoplasm (PEComa) of the gynecologic tract: morphology, immunophenotype, differential diagnosis. Am J Surg Pathol 2015;39:394-404.

34 Agaram NP, Sung YS, Zhang L, et al. Dichotomy of genetic abnormalities in PEComas with therapeutic implications. Am J Surg Pathol 2015;39:813-825. 